DE GRUYTER

OPEN

\title{
EMBRACING SUSTAINABLE DEVELOPMENT IS AN ETHICAL DECISION
}

ANNA PROŠKOVÁ 
The question of environmental protection seems to have become a widely discussed topic in recent years. There has been much debate as to what is the impact of human activity on issues like global warming, air and water pollution, waste generation, or depletion of resources, and how serious these problems really are. The increasing awareness of this topic has created a pressure on companies to implement measures leading to higher sustainability of their businesses. But is it really in the best interest of companies to embrace sustainability, or are they simply yielding to irrational pressure from the public as argued by Benjamin Hunt (2003) in his book The Timid Corporation? To be able to answer that question, a few terms must be clarified first.

Firstly, a clear definition of sustainable development is needed. Sustainable development was first defined by the World Commission on Environment and Development $(1987$, p. 8) in its report 'Our Common Future' as development that "meets the needs of the present without compromising the ability of future generations to meet their own needs." In other words, current development should be only as big as to not hinder future generations from enjoying the same possibilities as the current one. The second clarification needed is the definition of what the interests of a company are. Taking the stakeholder approach, where stakeholder is "any group or individual that can affect or is affected by the achievement of a corporation's purpose", as defined by Freeman (2004, p. 229), a company must take into account interests of all its stakeholders as opposed to only the interests of its shareholders. As Freeman (2004, p. 231) argues, it is in the interest of the company and its managers to consider effects of its actions on all stakeholders, and interests of the stakeholders need to be balanced over time. Consequently, the title of this paper could be rephrased as follows: Why might it be beneficial for a company and all of its stakeholders to do business in a way that will lead to preservation of environment for the future generations? Using first Bentham's utilitarianism, then Kant's categorical imperative, and finally Rawls's theory of justice as fairness, this paper will argue that it is in the interest of a company to embrace sustainable development because of the economic benefits for both stakeholders and shareholders, and because it provides a sound ethical commitment towards the future generations.

From the point of view of utilitarianism, embracing sustainable development is the ethical thing to do. As explained by Driver (2014), classical utilitarianism developed by Bentham and Mill is a consequencefocused theory that uses the utility principle of "the greatest good for the greatest number" to judge ethicality of actions. Using this principle, it can be argued that embracing sustainability is indeed the ethical thing to do as taken purely from the point of view of the greatest number of people benefiting from the action, and making the reasonable assumption that human kind will continue to exist for at least a few more centuries, it is clear that members of all the future generations vastly outnumber the current population of the Earth. Consequently, from the utilitarian point of view, future generations should be able to enjoy the same, if not greater benefits than the current one. Therefore, it is imperative for companies to behave in a sustainable manner that provides the future generations with this ability by preserving the environment.

Moreover, even from the short-term point of view, not taking into account the future generations, sustainable development brings substantial benefits to all of a company's stakeholders. According to Ambec and Lanoie (2005, p. 45), it is a common perception that implementation of sustainability measures in a company is costly, and therefore disadvantageous for shareholders. Even supposing this is true, the benefits (profits) created for shareholders by not adopting sustainability would be outweighed by the benefits sustainability would create for the overall society. The society is the stakeholder group greatest in number as many results of unsustainable behaviour of companies, such as air pollution or resources depletion, have worldwide consequences. Moreover, the environmental impacts caused by companies do not only have an impact on the quality of life of the society, but they also create costs for the society as elimination of the impacts is usually paid by the governments, which means from the taxes collected from their citizens and other companies. Therefore, a small number of people (the shareholders) would financially benefit, but a much larger number of people (the society) would be negatively impacted, making it unethical from the utilitarian point of view. 
Furthermore, as many companies have proven, a shift to sustainability if done the right way can lead to cost savings and higher sales, and therefore there is an economic benefit for the shareholders as well. This issue is discussed by Ambec and Lanoie (2008) who show that there has been much debate on whether reduction of waste and pollution leads to cost savings or not. Ambec and Lanoie (2008) conclude that while this cannot be generalised, there is a number of examples when shift to sustainability and cost reductions have gone hand in hand, giving among many the example of the WRAP Award programme that awards projects leading to waste reduction. Over the 22 years of its existence, the combined waste reduction of the awarded projects adds up to 230,000 tons and reduction of wastewater to 13 million tons, leading to savings of roughly $\$ 1$ billion as of 2008, according to Ambec and Lanoie (2008).

An exemplary company making a shift towards sustainable growth can be DuPont whose CEO Chad Holliday (2001, p. 4) argues that sustainability and business growth can go hand in hand, and that any company making a shift to sustainable development indeed needs to primarily focus on the economic value this shift will bring. An example of successful cost saving can be IBM's initiative of cutting on water and energy use resulting in $\$ 3$ million savings while increasing output by 33\%, as described by Chouinard, Ellison and Ridgeway (2011, p. 6), or Unilever's (2013, p. 7) combined savings of 350 million by waste reduction and energy saving. One more example is the project of the Washington State Department of Ecology (2007) that describes in its case study how its initiative helped the Canyon Creek Cabinet Company achieve annual savings of $\$ 1.19$ million while decreasing waste production and air emissions, and increasing productivity, product quality and safety.

Sales increase resulting from sustainability can be shown on the study by Trudel and Cotte (2009) that has proven that consumers are willing to pay more for products of companies operating in a sustainable manner. Moreover, due to this high environmental awareness of many consumers nowadays, companies can increase their sales not only by producing goods ethically and sustainably, but also by creating products that help their customers behave more sustainably, as shown by Unruh and Ettenson (2010, pp. 95-97) on the examples of Toyota entering the market of hybrid cars, or Brita's success in selling water filters by stressing that their use leads to lower use of plastic bottles. Therefore, adopting sustainable development can lead to a number of opportunities and benefits for both stakeholders and shareholders.

As has been shown so far, embracing sustainable development is the ethical thing to do from a consequentialist point of view as it creates the greatest good for the greatest number both in long term and short term view. However, consequentialism is only one of viewpoints of normative ethics. Another point of view would be missing if deontological theories of ethics were not used to assess the issue. As explained by Alexander and Moore (2012), deontological theories judge morality of a choice based on conformity with moral norms and 'rightness' of the act, focusing on the nature of the act itself regardless of its consequences. In the following section, the theories of Immanuel Kant and John Rawls will be used to address ethicality of sustainable development from the deontological point of view.

As explained by Johnson (2014), Kant argues that the basic principle of people's moral duties is a categorical imperative, the unconditional duty of people to act in a certain way based on several formulas. As described by Johnson (2014), these formulas say that the moral principles need to be universally applicable, other people must not be used as a means to an end, and people must act as they would wish anybody to act, in other words treat others as they would like to be treated themselves. Applying these principles to sustainable development, it is evident that conducting business in a non-sustainable manner is ethically wrong from Kant's perspective. A non-sustainable company clearly violates the categorical imperative as it creates value for the shareholders by harming other stakeholders such as the local community, the government, or even the future generations, using them as a means to their ends. Moreover, this is not universally applicable nor reversible as the shareholders certainly would not like to be treated in this manner if they were in the stakeholders' place. 
The case of Shell's operations in Nigeria could be given as an example. As described by Boele, Fabig and Wheeler (2001, pp. 74-78), Shell's oil drilling in the Niger Delta has had serious negative environmental and social impacts on the local community of the Ogoni people. Moreover, as Boele, Fabig and Wheeler (2001, pp. 74-78) point out, the Ogoni received next to nothing from enormous revenues generated from the oil as these were split between Shell, and the government who used it to finance all regions of Nigeria. This case clearly shows not only practical meaning and application of Kant's principles, but also the importance of using both consequentialist and deontological theories to assess an ethical issue as from the utilitarian point of view, the Ogoni people would be in minority compared to the whole population of Nigeria and all of Shell's shareholders and employees, therefore utilitarianism would deem Shell's actions ethical. However, from Kant's point of view, it is clear that the Ogoni people are being used by Shell and the Nigerian government as means to their own ends, and that these parties would definitely not wish to be treated this way if they were in the Ogonis' position. Consequently, from Kant's point of view, the actions of Shell and the Nigerian government are unethical. Another point of view from the deontological perspective is provided by John Rawls as will be discussed in the last section.

Rawls's theory, as explained by Wenar (2013), uses justice as fairness as the moral standard, using two principles as guidelines of justice; first, each person has a right for equal basic liberties that are compatible with the same liberties for everyone; second, there is a fair equality of opportunity for everyone to run for public positions, and the least-advantaged people have the greatest benefit from the society. As further described by Wenar (2013), to determine general principles of social justice, Rawls uses the original position which is an imaginary situation in which a group of people has to agree on terms of cooperation; these people are equal, free, reasonable and rational, and they do not know anything about themselves or their future conditions and position in the society. Therefore, when agreeing the terms, they need to make sure the society created based on these terms will be just and fair in case they fall into the most disadvantaged group, and find a balance of the terms that ensures fairness for everyone.

Applying Rawls's principles to sustainable development, the original position can be used to argue for what is fair and just. Supposing the group of people in the original position consists both of members of the current generation and the future one, they would need to find a balance of the agreed terms that will guarantee equal opportunities and freedom to both of these groups, hence coming back to the very definition of sustainable development - the current and future generations must have equal opportunities to meet their needs. Therefore Rawls's theory also confirms the conclusion that embracing sustainable development is the ethically correct thing to do for companies.

It is clear, therefore, that embracing sustainability is the ethical thing to do for companies based on both its consequences and ethicality of the act itself. As was argued using utilitarianism, embracing sustainable development is imperative for companies both in the short-term and the long-term view, taking into account benefits of both the current and the future generations. Moreover, implementation of sustainability measures can lead to economic benefits for the shareholders and other stakeholders as many real-life cases prove. As was further shown, sustainable development fulfills duties arising for companies from the categorical imperative, and complies with Rawls's principles of justice as fairness. All these perspectives and arguments lead to the same conclusion that embracing sustainable development is in the interest of a company because of the economic benefits for both stakeholders and shareholders, and because it provides a sound ethical commitment towards the future generations. 


\section{REFERENCES}

Alexander, L. and Moore, M. (2012) 'Deontological Ethics', The Stanford Encyclopedia of Philosophy, Winter [Online]. Available at: http://plato.stanford.edu/entries/ethics-deontological/\#DeoThe (Accessed: 10 December 2014).

Ambec, S. and Lanoie, P. (2008) 'Does It Pay to Be Green? A Systematic Overview', Academy of Management, 22(4), pp. 45 - 62. Boele, R., Fabig, H. and Wheeler, D. (2001) 'Shell, Nigeria and the Ogoni. A Study in Unsustainable Development: I. The Story of Shell, Nigeria and the Ogoni People - Environment, Economy, Relationships: Conflict and Prospects for Resolution', Sustainable Development, 9, pp. $74-86$.

Chouinard, Y., Ellison, J. and Ridgeway, R. (2011) 'The Sustainable Economy', Harvard Business Review, 89 (October), p. 6.

Driver, J. (2014) 'The History of Utilitarianism', The Stanford Encyclopedia of Philosophy, Winter [Online]. Available at: http:/ / plato.stanford.edu/entries/utilitarianism-history/\#JerBen (Accessed: 3 December 2014).

Freeman, E. (2004) 'The Stakeholder Approach Revisited', zfwu, 5(3), pp. 229-231.

Holliday, C. (2001) 'Sustainable Growth, the DuPont Way', Harvard Business Review, 79 (September), p. 4.

Hunt, B. (2003) The Timid Corporation: Why Business is Terrified of Taking Risk. Great Britain: John Wiley er Sons.

Johnson, R. (2014) 'Kant's Moral Philosophy', The Stanford Encyclopedia of Philosophy, Summer [Online]. Available at: http:// plato.stanford.edu/entries/kant-moral/ (Accessed: 9 December 2014).

Trudel, R. and Cotte, J. (2009) 'Does It Pay to Be Good?', MIT Sloan Management Review, 50(2), pp. 61-68.

Unilever (2013) Unilever Sustainable Living Plan 2013: Making Progress, Driving Change [Online]. Available at: http:/ /www. unilever.com/images/slp_Unilever-Sustainable-Living-Plan-2013_tcm13-388693.pdf (Accessed: 10 December 2014).

Unruh, G. and Ettenson, R. (2010) 'Growing Green', Harvard Business Review, 88 (June), pp. 94-100.

Washington State Department of Ecology (2007) Lean er Environment Case Study: Canyon Creek Cabinet Company [Online]. Available at: https://fortress.wa.gov/ecy/publications/publications/0604024.pdf (Accessed: 12 December 2014).

Wenar, L. (2013) 'John Rawls', The Stanford Encyclopedia of Philosophy, Winter [Online]. Available at: http://plato.stanford.edu/ entries/rawls/ (Accessed: 10 December 2014).

World Commission on Environment and Development (1987) Our Common Future. Great Britain: Oxford University Press. 